\title{
EVALUASI IMPLEMENTASI PENDIDIKAN KARAKTER PADA PEMBELAJARAN FISIKA DI MAN YOGYAKARTA I
}

\author{
Sudra Irawan \\ Politeknik Negeri Batam \\ email: sudra@polibatam.ac.id
}

\begin{abstract}
Abstrak: Penelitian ini bertujuan untuk mengevaluasi implementasi pendidikan karakter pada pembelajaran fisika di MAN Yogyakarta I. Jenis penelitian ini adalah penelitian evaluasi dengan menggunakan model CIPP (contexts, input, process, and product). Pengumpulan data dilakukan dengan teknik dokumentasi, tes, kuesioner, observasi, wawancara, dan triangulasi. Teknik analisis data menggunakan teknik analisis deskriptif kualitatif dan deskriptif kuantitatif. Hasil analisis deskriptif menunjukkan bahwa MAN Yogyakarta I baik $(79,14 \%)$ dalam mengimpelemtasikan pendidikan karakter pada pembelajaran fisika yang dibuktikan dengan tumbuhnya 18 nilai karakter pada diri siswa. Hasil aspek-aspek implementasi, yaitu kesiapan guru fisika berkategori baik $(71,14 \%)$ dengan iklim pembelajaran yang cukup kondusif, perencanaan pembelajaran fisika pada kategori sangat baik $(81,59 \%)$, pelaksanaan pembelajaran fisika di kelas pada kategori baik $(79,97 \%)$, pelaksanaan evaluasi pembelajaran fisika oleh guru pada kategori baik $(81,25 \%)$, dan kinerja guru fisika pada kategori baik $(81,16 \%)$. Kendala utama yang dihadapi berasal dari faktor guru. Alokasi jam pelajaran fisika yang ada pada kurikulum dinilai oleh guru kurang untuk menyampaikan materi pelajaran dan kegiatan eksperimen sehingga pilar karakter sulit dikembangkan oleh siswa.
\end{abstract}

Kata Kunci: evaluasi, pendidikan karakter, pembelajaran fisika, MAN Yogyakarta I

\section{EVALUATING THE IMPLEMENTATION OF CHARACTER EDUCATION IN PHYSICS LEARNING AT MAN YOGYAKARTA I}

\begin{abstract}
This study aimed to evaluate the implementation of character education in physics learning at MAN Yogyakarta I. This research is of the evaluation type using the model of CIPP (context, input, process, and product). The data collection was done by using the documentation, tests, questionnaires, observations, interviews. Data reliability was obtained through triangulation technique. Data were analyzed using qualitative and quantitative descriptive analysis techniques. The descriptive analysis result showed that MAN Yogyakarta I was good (79.14\%) in impelemting character education in physics learning as indicated by the growth of 18-character values on students. The results of the implementation aspects, namely the readiness of physics teacher in the good category $(71.14 \%)$ with a conducive learning climate, physics lesson plan in the very good category $(81.59 \%)$, the implementation of physics learning in the classroom in the good category $(79,97 \%)$, the evaluation of physics learning by teachers in the good category $(81.25 \%)$, and physics teachers' performance in the good category $(81.16 \%)$. The main obstacle confronted came from the teacher factor. The allocation of physics teaching hours in the curriculum as assessed by teachers was insufficient for delivering course material and experimentation activities so that character pillars were difficult for the students to develop.
\end{abstract}

Keywords: evaluation, character education, physics learning, MAN Yogyakarta I

\section{PENDAHULUAN}

Pendidikan karakter merupakan segala sesuatu yang dilakukan guru untuk mempengaruhi karakter peserta didik. Guru membantu dalam membentuk watak peserta didik dengan memberikan keteladanan, cara berbicara atau menyampaikan ma- teri yang baik, toleransi, dan berbagai hal yang terkait lainnya (Asmani, 2011:31). Nilai karakter ini dapat dibedakan menjadi lima nilai utama, yaitu nilai-nilai prilaku manusia dalam hubungannya dengan Tuhan Yang Maha Esa, diri sendiri, sesama manu- 
sia, lingkungan, dan kebangsaan (Hamid, 2008)

Prinsip-prinsip dasar pendidikan karakter di sekolah, yaitu:(1) mempromosikan nilai-nilai dasar etika sebagai basis karakter; (2) mengidentifikasi karakter secara komprehensif supaya mencakup pemikiran, perasaan, dan perilaku; (3) menggunakan pendekatan tajam, proaktif, dan efektif untuk membangun karakter; (4) menciptakan komunitas sekolah yang memiliki kepedulian; (5) memberikan kesempatan kepada peserta didik membangun karakter mereka dan membantu mereka untuk sukses; (6) memiliki cakupan terhadap kurikulum yang bermakna dan menantang yang menghargai semua peserta didik; (7) mengusahakan tumbuhnya motivasi dari peserta didik; (8) memfungsikan seluruh staf sekolah sebagai komunitas moral yang berbagi tanggung jawab untuk pendidikan karakter dan setia pada nilai-nilai dasar yang sama; (9) adanya pembagian kepemimpinan moral dan dukungan luas dalam membangun pendidikan karakter; (10) memfungsikan keluarga dan anggota masyarakat sebagai mitra dalam usaha membangun karakter; dan (11) mengevaluasi karakter sekolah, fungsi staf sekolah sebagai guru-guru pendidikan karakter dan manifestasi positif dalam kehidupan peserta didik (Gunawan, 2012:35).

Langkah-langkah pelaksanaan pendidikan karakter di sekolah meliputi: (1) perencanaan, yaitu mengidentifikasi jenisjenis kegiatan di sekolah yang dapat merealisasikan pendidikan karakter, mengembangkan materi pendidikan karakter untuk setiap jenis kegiatan di sekolah, mengembangkan rancangan pelaksanaan setiap kegiatan, dan menyiapkan fasilitas pendukung pelaksanaan program pendidikan karakter; (2) implementasi, yaitu pembentukan karakter yang terpadu dengan pembelajaran pada semua mata pelajaran, pem- bentukan karakter yang terpadu dengan managemen sekolah, pembentukan karakter dengan kegiatan kependidikan; dan (3) monitoring dan evaluasi, yaitu kegiatan untuk memantau proses pelaksanaan program pendidikan karakter, yang terfokus pada kesesuaian proses pelaksanaan program pendidikan karakter berdasarkan tahapan atau prosedur yang ditetapkan (Fathurrahman, 2013:193)

MAN Yogyakarta I telah melaksanakan pendidikan karakter melalui Kurikulum KTSP sejak tahun 2006, namun sampai sekarang belum ada penelitian terhadap implementasi pendidikan karakter yang bersifat evaluatif. Hal ini tentu belum teridentifikasinya ketercapaian kurikulum dan hambatan-hambatan atau kendala-kendala dalam implementasi pendidikan karakter di lapangan. Selain itu, belum ada evaluasi program di MAN Yogyakarta I dalam pembelajaran yang mencakup aspek kesiapan guru, perencanaan pembelajaran, pelaksanaan pembelajaran, dan evaluasi pembelajaran yang dilakukan guru. Dari sudut pandang itulah kiranya perlu diadakan penelitian untuk mengetahui sejauhmana implementasi pendidikan karakter di MAN Yogyakarta I.

Penelitian inibertujuan untuk mengetahui sejauhmana: (1) kesiapan guru fisika dan iklim pembelajaran di MAN Yogyakarta I dalam mengimplementasikan pendidikan karakter, khususnya pada pembelajaran fisika; (2) perencanaan pembelajaran pendidikan karakter yang dilakukan oleh guru fisika; (3) pelaksanaan pembelajaran pendidikan karakter yang dilakukan oleh guru fisika; (4) evaluasi pembelajaran pendidikan karakter yang dilakukan oleh guru fisika; (5) kinerja guru fisika dan prestasi MAN Yogyakarta I setelah dilaksanakan pendidikan karakter pada pembelajaran fisika; dan (6) kendala-kendala dalam implemen- 
tasi pendidikan karakter di MAN Yogyakarta I pada pembelajaran fisika.

Hasil penelitian ini diharapkan dapat dijadikan informasi dan dasar pengambilan kebijakan pendidikan di MAN Yogyakarta I, terutama dalam rangka pengembangan pendidikan karakter dan implementasi kurikulum terbaru. Selain itu, sebagai umpan balik atau masukan yang membangun bagi guru fisika agar senantiasa berupaya untuk meningkatkan kualitas proses pembelajaran baik di kelas maupun di laboratorium yang berwawasan iman dan taqwa serta berwawasan ilmu pengetahuan dan teknologi.

\section{METODE}

Jenis penelitian ini adalah penelitian evaluasi yang difokuskan pada evaluasi implementasi pendidikan karakter dalam pembelajaran fisika dengan menggunakan model CIPP (Contexts, Input, Process, and Product). Evaluasi program meliputi pelaksanaan suatu program dengan penekanan pada evaluasi konteks, masukan, proses, dan produk (Prasetyo, 2001). Dalam penelitian ini evaluasi contexts (konteks) meliputi kesiapan guru, iklim pembelajaran dan kendala-kendala dalam implementasi pendidikan karakter. Evaluasi input (masukan), yaitu perencanaan pembelajaran oleh guru fisika yang meliputi: identifikasi kebutuhan KBM, penyusunan silabus, dan RPP. Evaluasi process (proses) yang meliputi: pelaksanaan pembelajaran fisika di kelas dan pelaksanaan evaluasi pembelajaran yang dilakukan guru fisika. Evaluasi product (hasil) meliputi kinerja guru dan prestasi siswa.

Subjek dalam penelitian ini adalah seluruh guru fisika yang ada di MAN Yogyakarta I berjumlah 3 orang yang mengajar di kelas X, XI, dan XII. Data dikumpulkan dengan teknikdokumentasi, tes, kue- sioner, observasi, wawancara, dan triangulasi. Dokumentasi yang diperoleh dalam penelitian ini sebagai data pada perencanaan pembelajaran fisika berupa silabus dan sistem penilaian serta rencana pelaksanaan pembelajaran (RPP) yang dibuat oleh guru fisika. Dokumen evaluasi hasil pelaksanaan pembelajaran fisika berupa daftar nilai dan tabel analisis hasil ulangan yang dimiliki guru. Tes, dalam hal ini menguji pengetahuan guru tentang pemahaman pendidikan karakter dalam kurikulum secara umum yang meliputi aspek: konsep kompetensi, hakikat kurikulum, pengembangan kurikulum pendidikan karakter, penyusunan silabus dan RPP berorientasi pendidikan karakter, dan sistem penilaian. Data yang dikumpulkan dengan teknik kuesioner adalah data kesiapan guru fisika (pemahaman pedoman khusus pendidikan karakter fisika dan pengalaman mengajar) dan evaluasi kinerja guru oleh siswa. Teknik observasi digunakan untuk mengumpulkan data tentang implementasi pendidikan karakter yang meliputi perencanaan pembelajaran, pelaksanaan pembelajaran, dan perlengkapan pembelajaran, proses pembelajaran, para pelaku dan aktivitas sosial yang sedang berlangsung yang tidak dapat terungkap dalam teknik wawancara. Wawancara diperlukan untuk mengetahui kendala-kendala yang dihadapi oleh guru fisika di MAN Yogyakarta I dalam mengimplementasikan pendidikan karakter.

Keabasahan data dilakukan dengan teknik triangulasi dengan melakukan pemeriksaan data yang diperoleh dari seluruh guru fisika, peneliti, kepala sekolah, dan siswa. Triangulasi dilakukan pada setiap tahapan CIPP, yaitu konteks, input, proses, dan produk.

Jenis validitas yang digunakan dalam penelitian adalah validitas logis (teoretis) yang meliputi validitas isi (content validity), 
validitas konstruk (construct validity) dan validitas emperis. Data yang diperoleh berupa data kualitatif dan kuantitatif sehingga teknik analisis data menggunakan teknik analisis deskriptif kualitatif dan deskriptif kuantitatif. Analisis deskriptif kualitatif digunakan untuk menganalisis data yang diperoleh selama penelitian berupa hasil catatan observasi dan hasil wawancara, sedangkan analisis deskriptif kuantitatif digunakan untuk menganalisis data berupa hasil tes, kuesioner, dan penilaian observasi. Cara analisis deskriptif kuantitatif dilakukan dengan cara membandingkan implementasi pendidikan karakter dalam pembelajaran fisika dengan kriteria penilaian yang sudah ditentukan, untuk selanjutnya ditentukan presentasenya.

\section{HASIL DAN PEMBAHASAN}

\section{Analisis Kesiapan Guru Fisika}

Guru fisika di MAN Yogyakarta I mempunyai pemahaman terhadap konsep pendidikan karakter kategori cukup baik $(54,45 \%)$, pemahaman pedoman khusus pendidikan karakter fisika kategori sangat baik $(89,04 \%)$. Dengan demikian, secara keseluruhan kesiapan guru fisika MAN Yogyakarta I memiliki kategori baik dengan persentase rata-rata sebesar $71,74 \%$.

Guru yang kurang baik dalam dalam memahami pendidikan karakter dalam kurikulum ditunjukkan dengan kebingungan dalam membuat perencanaan pembelajaran, pelaksanaan pembelajaran, dan perencanaan evaluasi hasil belajar siswa karena guru tidak tahu apa yang harus dilakukan. Pemahaman guru ini diperoleh dari pengalaman mengajar dan diklat atau sosialisasi pendidikan karakter dan kurikulum yang pernah diikuti. Selain itu, untuk menunjang pelaksanaan implementasi pendidikan karakter pada kurikulum, guru MAN Yogyakarta I setiap awal tahun diberi 3 macam buku yaitu buku I, buku II, dan buku III. Buku I berisi standar kompetensi, kompetensi dasar, silabus, dan RPP. Buku II berisi program semester, program tahunan, kalender pendidikan, dan agenda kegiatan belajar mengajar. Buku III berisi daftar nilai, presensi siswa, program remedial dan pengayaan, serta analisis ulangan siswa.

MAN Yogyakarta I telah menerapkan Kurikulum 2013. Pelaksanaan Kurikulum 2013 di MAN Yogyakarta I lebih menekankan pada tiga ranah yang perlu dinilai yaitu sikap, pengetahuan, dan keterampilan. Sikap menjadi penilaian paling utama sebelum menilai kedua hal setelah itu. Dalam Kurikulum 2013 sikap tertuang dalam Kompetensi Inti (KI) satu sampai empat, dan termuat juga dalam Kompetensi Dasar (KD) satu dan dua. Pengetahuan baru dimulai pdaa KD tiga dan keterampilan di KD empat. Dengan demikian, penilaian siswa MAN Yogyakarta I seluruhnya diserahkan pada sikap bukan hanya pada kognitif semata seperti pelaksanaan ujian nasional (UN) selama ini. Dalam Kurikulum 2013 dikenal pendekatan scientific. Pendekatan ini lebih menekankan pada pembelajaran yang mengaktifkan siswa. Pendekatan ini paling tidak dilaksanakan dengan melibatkan tiga model pembelajaran, yaitu problem based learning, project based learning, dan discovery learning.

Selama ini, guru menganggap bahwa mengajar itu mudah dan enak karena guru hanya mengikuti apa yang sudah ada dalam buku-buku yang tersedia tanpa harus merisaukan apakah siswa bisa paham atau tidak, yang penting guru selesai dalam memberikan materi pelajaran sesuai dengan GBPP (Hamid dan Hasan, 2007:3). Anggapan seperti ini harus segera diubah karena dalam Kurikulum 2013 guru dituntut berinovasi agar pembelajaran yang dilaksanakan dapat lebih menarik sehingga 
siswa akan enjoy dan tidak cepat bosan dalam belajar. Kebanyakan siswa menganggap pelajaran fisika merupakan mata pelajaran yang paling sulit karena banyak menggunakan rumus-rumus dan perhitungan (Suparno, 2006:9)

\section{Perencanaan Pembelajaran Fisika}

Hasil analisis terhadap 12 KD yang berhasil direncanakan oleh guru fisika diperoleh bahwa perencanaan pembelajaran fisika kelas X dan kelas XI di MAN Yogyakarta I mempunyai kategori sangat baik dengan persentase sebesar 81,59\%. Hal ini berarti guru fisika MAN Yogyakarta I sangat baik dalam membuat perencanaan pembelajaran fisika seperti terlihat pada Gambar 1.

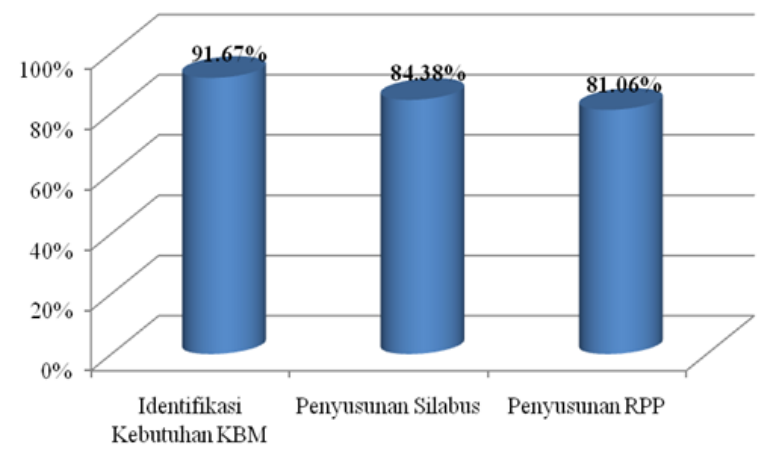

Gambar 1. Hasil Analisis Aspek Perencanaan Pembelajaran Fisika

Terdapat 27 perangkat pembelajaran yang harus dimiliki oleh seluruh guru termasuk guru fisika di MAN Yogyakarta I yaitu: (1) silabus; (2) Rencana Pelaksanaan Pembelajaran (RPP); (3) program tahunan, (4) program semester; (5) kalender pendidikan; (6) buku pelaksanaan harian, (7) presensi siswa; (8) catatan hambatan belajar siswa; (8) daftar buku pegangan siswa;

(9) Rencana Pelaksanaan Harian (RPH);

(10) Buku Pelaksanaan Harian (BPH); (11) Kriteria Ketuntasan Minimum (KKM); (11) kisi-kisi soal; (12) soal-soal ulangan; (13) buku informasi penilaian; (14) analisis butir soal; (15) analisis hasil ulangan; (16) program pelaksanaan perbaikan; (17) program pelaksanaan pengayaan; (19) daftar pengembalian hasil ujian, (20) buku ulangan bergilir; (21) daftar nilai; (22) laporan penilaian akhlak mulia dan kepribadian siswa; (23) buku tugas terstruktur; (24) buku tugas mandiri; (25) SK pembagian tugas; (26) mengisi buku kemajuan kelas; dan (27) jadwal mengajar.

Perencanaan pembelajaran fisika yang dilakukan guru MAN Yogyakarta I meliputi identifikasi kebutuhan KBM, penyusunan silabus, dan penyusunan rencana pelaksanaan pembelajaran (RPP), dan penyusunan sistem penilaian. Hasil penelitian menunjukkan bahwa guru fisika MAN Yogyakarta I telah sangat baik pada semua aspek dari perencanaan pembelajaran baik mengidentifikasi kebutuhan KBM dengan persentase $91,67 \%$, penyusunan silabus dengan persentase $84,38 \%$, dan penyusunan rencana pelaksanaan pembelajaran dengan persentase $81,06 \%$. Oleh karena itu, secara keseluruhan diperoleh persentase sebesar 81,59\% dengan kategori baik.

\section{Pelaksanaan Pembelajaran Fisika}

Hasil analisis menunjukkan bahwa pelaksanaan pembelajaran fisika dari 12 KD mempunyai kategori baik dengan persentase sebesar 79,97\% (Gambar 2). Ini berarti guru fisika MAN Yogyakarta I telah baik dan mampu mengelolah pembelajaran di kelas. Hal ini karena mereka memiliki motivasi tersendiri dalam melaksanakan tugas dan kewajiban mereka sebagai guru: (1) mengajar adalah ibadah; (2) mengajar adalah pekerjaan yang mulia; dan (3) keberhasilan siswa merupakan harapan, kepuasan dan kesuksesan guru dalam mengajar. 


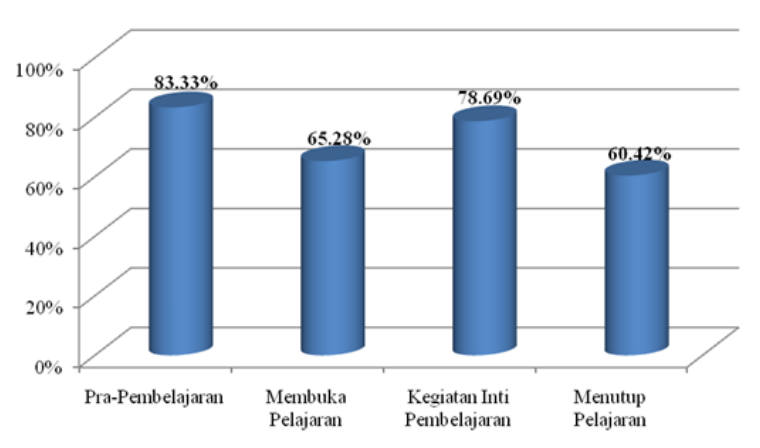

Gambar 2. Hasil Analisis Aspek Pelaksanaan Pembelajaran Fisika

Dalam pelaksanaan pembelajaran guru sudah cukup memahami keberagaman siswa. Hal ini terlihat dari sikap dan perhatian guru selama pembelajaran berlangsung. Secara umum, guru tidak segan menanyakan kepada siswa tentang hal-hal yang belum bisa dipahami terkait dengan materi yang disampaikan. Di samping itu, kedekatan siswa terhadap guru cukup baik. Sebagian besar guru merasa siswa adalah teman untuk belajar.

Secara rinci persentase masing-masing aspek pelaksanaan pembelajaran pendidikan karakter fisika kelas X dan kelas XI MAN Yogyakarta I menunjukkan kegiatan pra-pembelajaran, penguasaan materi pelajaran, pendekatan dan strategi pembelajaran, pembelajaran yang memicu dan memelihara keterlibatan siswa memiliki kategori sangat baik. Secara umum, hal itu sudah baik, tetapi kegiatan membuka pelajaran (58,33\% berkategori cukup) dan menutup pelajaran $(54,16 \%$ berkategori cukup) perlu ditingkatkan oleh guru agar pembelajaran dapat berlangsung efektif dan efisien. Kegiatan membuka pelajaran mencakup melakukan kegiatan apersepsi, memotivasi siswa, dan menyampaikan kompetensi yang akan dicapai. Kegiatan menutup pelajaran terdiri atas melakukan refleksi atau membuat rangkuman dengan melibatkan siswa dan melaksanakan tindak lanjut dengan memberikan arahan kegiatan, atau tugas yang menjadi pekerjaan rumah siswa.

Pelaksanaan pendidikan karakter pada pembelajaran fisika, yang berada pada kategori sangat baik adalah kegiatan prapembelajaran, penguasaan materi, pendekatan dan strategi pembelajaran, dan pembelajaran yang memicu dan memelihara keterlibatan siswa. Untuk kategori baik dengan nilai persentase yang kurang dari $70 \%$, terdapat pada aspek membuka pelajaran, penggunaan media dan metode pembelajaran, dan menutup pelajaran. Ketiga aspek ini harus segera ditanggulangi oleh guru fisika di MAN Yogyakarta agar pembelajaran dapat berlangsung asyik dan menyenangkan tentu dengan mengimplementasikan aspek iman dan takwa dalam proses pembelajaran.

Berdasarkan pengamatan peneliti di lapangan dan wawancara dengan guru dan mahasiswa pembelajaran fisika di MAN Yogyakarta I telah menumbuhkan sikap religius, jujur, toleransi, disiplin, kerja keras, kreatif, mandiri, demokratis, rasa ingin tahu, semangat kebangsaan, cinta tanah air, menghargai prestasi, bersahabat/komunikatif, cinta damai, gemar membaca, peduli lingkungan, peduli sosial, dan tanggung jawab. Guru menumbuhkan sikap-sikap tersebut dalam proses pembelajaran.

\section{Pelaksanaan Evaluasi Pembelajaran Fisika}

Hasil analisis terhadap cara guru mengevaluasi pembelajaran fisika siswa menunjukkan kategori baik dengan persentase sebesar $81,25 \%$ dengan persentase masing-masing aspek yang dinilai diperlihatkan pada Gambar 3.

Hal ini berarti selama satu semester terahir guru fisika sudah baik dalam melaksanakan evaluasi pembelajaran. Dalam sistem managemen, evaluasi sangat penting untuk mengetahui tingkat keberhasilan 


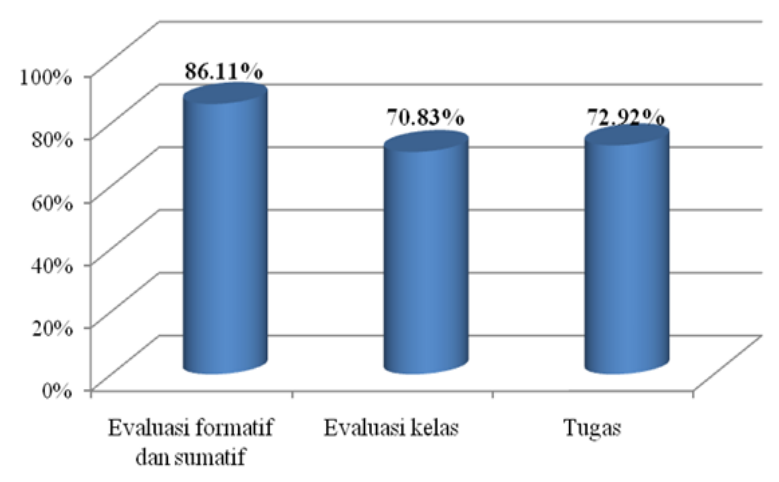

\section{Gambar 3. Histogram Hasil Tiap Aspek Pelaksanaan Evaluasi Pembelajaran}

dalam melaksanakan suatu program. Selain itu, dengan evaluasi juga dapat diketahui apakah proses pembelajaran berjalan dengan optimal atau tidak.

Berdasarkan hasil observasi di lapangan dan wawancara dengan guru, ulangan harian yang dilakukan guru fisika kelas $X$ dan kelas XI ada yang dilakukan pada tiaptiap KD atau beberapa KD. Hal ini mengingat waktu yang tersedia untuk pelajaran fisika sangat terbatas, yaitu 2 jam pelajaran untuk kelas $X$ dan 5 jam pelajaran untuk kelas XI setiap minggunya. MID semester dilakukan dengan mengevaluasi gabungan dari beberapa KD. Jadi, dalam penelitian ini ulangan formatif sama dengan ulangan harian. Ulangan sumatif sama dengan MID semester dan ujian akhir semester (UAS). Khusus untuk UAS, soal dibuat di tingkat provinsi dan mencakup keseluruhan materi selama satu semester. Pada saat UAS semua madrasah yang ada di Yogyakarta memperoleh soal yang sama dengan tingkat kesulitan yang sama pula.

Prinsip belajar yang dikembangkan di MAN Yogyakarta I adalah prinsip belajar tuntas (mastery learning). Dalam pembelajaran tuntas ini siswa harus menguasai semua standar kompetensi dan kompetensi dasar yang telah ditentukan. Bagi siswa yang sudah mencapai ketuntasan diberikan program pengayaan sedangkan siswa yang belum tuntas diberi program remedial. Ketuntasan belajar ditentukan berdasarkan hasil analisis ulangan harian dan MID semester. Standar ketuntasan untuk mata pelajaran fisika tahun ajaran 2012/ 2013 kelas X semester gasal adalah 60 sedangkan kelas XI semester gasal adalah 65 .

Program remedial dilaksanakan di luar jam regular, setelah PBM berlangsung dengan menjawab soal remedial yang telah dibuat oleh guru. Program remedial ada juga dalam bentuk pemberian tugas individu atau kelompok. Sementara untuk program pengayaan dilaksanakan dengan kegiatan tutor sebaya. Artinya, siswa yang sudah mencapai ketuntasan diminta guru untuk membantu mengajar bagi siswa yang belum tuntas. Program remedial dan pengayaan ini dilakukan secara klasikal. Untuk program remedial, guru memberikan batasan sebanyak 3 kali dengan ketentuan nilai akhir yang dijadikan pertimbangan dalam nilai rapor.

Berdasarkan hasil wawancara dan observasi kelas serta dokumen yang dimiliki oleh guru fisika pada kelas $X$, dalam satu semester guru melaksanakan 2 kali ulangan harian, 1 kali MID semester dan 1 kali ujian akhir semester (UAS). Pada kelas XI dalam setiap semester guru melaksanakan 3 kali ulangan harian, 1 kali MID semester, dan 1 kali UAS. Setiap selesai ulangan harian guru melakukan analisis terhadap hasil ulangan. Hal ini dilakukan untuk mengetahui siswa yang sudah mencapai ketuntasan dan siswa yang belum mencapai ketuntasan. Selanjutnya, dilakukan tindak lanjut berupa remedial atau pengayaan.

Jenis tagihan yang diberikan kepada siswa antara lain: kuis, tugas individu dan kelompok, pekerjaan rumah (PR), ulangan harian, MID semester, portofolio, dan tugas unjuk kerja (TUK) yang masing-masing tugas mengandung pilar pendidikan karakter, 
yaitu kerja sama, toleransi, kebersamaan, percaya diri, dan lain-lain. Tugas unjuk kerja berupa mengerjakan soal di depan kelas dan presentasi tugas. Nilai kognitif yang dicapai siswa berasal dari $25 \%$ ratarata hasil penilaian kelas ditambah $75 \%$ rata-rata hasil ulangan harian, MID semester, dan ulangan semester. Penilaian kelas berasal dari masing-masing tagihan yang diminta oleh guru. Nilai afektif berasal dari nilai sikap, kerja sama, kreativitas, presensi, dan kelengkapan tugas. Nilai psikomotorik berasal dari nilai kegiatan praktikum seperti menyiapkan peralatan, menyusun perangkat percobaan, melaksanakan praktikum, dan menyusun laporan praktikum. Hasil nilai kognitif dan psikomotorik berupa angka dengan rentang nilai $0-100$, sedangkan nilai afektif dengan huruf yaitu $\mathrm{A}$ = sangat baik, $\mathrm{B}=$ baik, $\mathrm{C}=$ cukup, $\mathrm{D}=\mathrm{ku}$ rang.

Evaluasi pembelajaran meliputi aspek formatif dan sumatif, evaluasi kelas, dan tugas. Evaluasi formatif berupa ulangan harian sedangkan evaluasi sumatif berupa ulangan akhir semester. Evaluasi formatif dan sumatif yang dilakukan guru fisika MAN Yogyakarta I sudah sangat baik, dengan persentase mencapai $86,11 \%$, ini berarti semua guru fisika sudah mampu melaksanakan evaluasi formatif dan evaluasi sumatif dengan sangat baik. Di samping itu, evaluasi kelas yang dilakukan guru juga sudah baik dengan persentase $70,83 \%$. Ini berarti guru sudah mampu mengelolah kelas dengan baik sehingga tercipta lingkungan belajar yang kondusif. Keadaan kondusif terlihat pada pembelajaran yang berjalan secara efektif dan efisien. Tugas yang diberikan guru juga masuk dalam kategori baik sebesar $72,92 \%$. Ini menunjukkan guru telah mampu memberikan tugas dan intensitas tugas sesuai dengan tujuan pembelajaran yang ingin di- capai. Jadi, secara umum evaluasi belajar fisika siswa dalam pendidikan karakter yang dilakukan oleh guru fisika MAN Yogyakarta I sudah baik.

\section{Kinerja Guru dan Siswa MAN Yogyakar- ta I}

Kinerja guru meliputi 4 aspek yaitu kemampuan guru dalam mengajar (menyampaikan materi pelajaran), metode dan media pembelajaran, komunikasi, serta sikap dan kepribadian guru. Hasil analisis pada masing-masing aspek menunjukkan bahwa semua aspek menunjukkan kategori baik dengan persentase kemampuan mengajar sebesar $86,22 \%$, metode dan strategi pembelajaran $74,03 \%$, komunikasi $83,32 \%$, serta sikap dan kepribadian sebesar 80,79\%, sehingga diperoleh persentase rata-rata sebesar $81,16 \%$ yang termasuk dalam kategori baik (Gambar 4). Hal ini sesuai dengan harapan bahwa seorang guru dikatakan sukses dalam mengajar apabila kepala madrasah, guru sejawat, dan peneliti mengatakan guru baik dalam mengimplementasikan keempat aspek kinerja guru.

Kemampuan guru fisika MAN Yogyakarta I baik dengan persentase $86,11 \%$ dalam mengajar ditandai dengan beberapa indikator yang telah dicapai guru, yaitu: (1) kemampuan guru dalam menjelaskan materi ajar sudah runtut, jelas, dan mudah dipahami siswa; (2) kemampuan guru dalam penilaian hasil belajar siswa sudah sesuai dengan tujuan pembelajaran; (3) guru sudah mampu memimpin kelas; dan (4) guru telah mampu menerapkan hal-hal baru dalam pembelajaran fisika. Jika aspek ini diterapkan guru secara konsisten, maka anggapan siswa bahwa pelajaran fisika adalah pelajaran yang sulit, sedikit demi sedikit akan memudar berubah menjadi pembelajaran fisika yang asyik dan menyenangkan. 


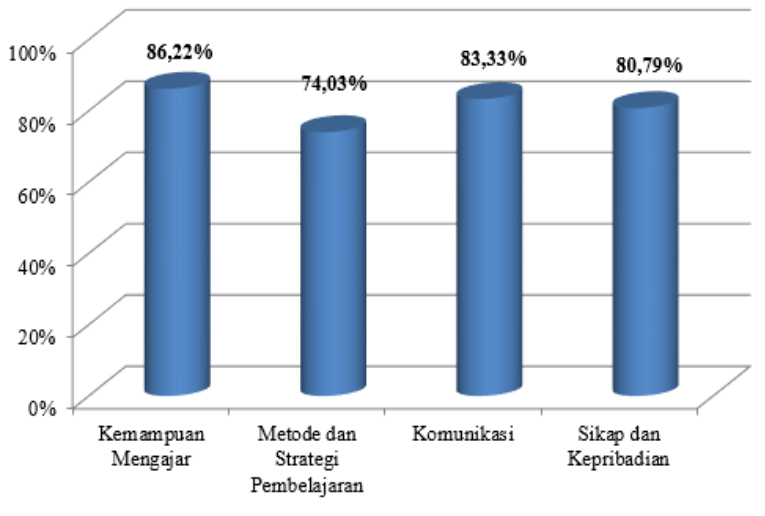

Gambar 4. Kinerja Guru MAN

Yogyakarta I dalam Implementasi Pendidikan Karakter

Kemampuan guru fisika MAN Yogyakarta I dalam membuat media dan mengembangkan metode pembelajaran fisika dikatakan baik dengan persentase $74,03 \%$ apabila guru telah mampu menggunakan media dalam mengajar, menggunakan berbagai metode dalam mengajar, dan kemampuan mengelolah interaksi belajar mengajar. Guru dikatakan baik dalam berkomunikasi, dengan persentase $83,32 \%$ ditandai beberapa indikator, yaitu: (1) kejelasan bahasa, tulisan, dansuara guru; (2) guru memberikan kesempatan siswa dalam bertanya; (3) guru mampu memicu dan memelihara keterlibatan siswa; dan (4) guru melakukan layanan bimbingan belajar.

Guru fisika MAN Yogyakarta I memiliki sikap dan kepribadian baik, dengan persentase $80,79 \%$ apabila guru memiliki sikap kedisiplinan, tanggungjawab, kasih sayang, penghargaan terhadap siswa, stabilitas emosi, komitmen, objektivitas menilai yang tinggi. Sikap dan kepribadian ini dapat membuat siswa merasa nyaman dalam belajar fisika.

\section{Kendala-kendala dalam Implementasi Pendidikan Karakter}

Hasil wawancara dengan ketiga guru fisika MAN Yogyakarta I menunjukkan bah- wa terdapat kendala-kendala pelaksanaan pendidikan karakter dalam pembelajaran fisika walaupun masalahnya bersifat umum dan rata-rata setiap sekolah mengalaminya. Masalah yang muncul antara lain meliputi: jumlah rombongan belajar terlalu besar, laboratorium yang belum difungsikan secara maksimal, minat baca siswa yang masih rendah di perpustakaan, dan kekurangan waktu yang dialami guru dalam proses pembelajaran fisika.

Sarana dan prasarana di MAN Yogyakarta I terdiri dari media pembelajaran keras dan lunak. Media pembelajaran keras seperti alat-alat peraga dan alat-alat praktikum cukup memadai, tetapi belum difungsikan secara maksimal untuk kegiatan pembelajaran. Media pembelajaran keras yang ada di MAN Yogyakarta I adalah papan tulis, (white board), VCD player, OHP, LCD, tape recorder, infocus, dan internet. Jumlah $L C D$ dan OHP bertambah dari tahun sebelumnya, tetapi selama pengamatan peneliti selama satu semester, guru belum pernah menggunakan $L C D$ ataupun $O H P$ dalam kegiatan pembelajaran. Pihak madrasah bekerja sama dengan komite madrasah, dan beberapa pihak setiap tahunnya selalu menganggarkan dana untuk pembelian media pembelajaran seperti $O H P, L C D$, dan lain-lain. Media pembelajaran semakin lengkap agar proses pembelajaran berlangsung secara efektif dan efisien. Perangkat pembelajaran lunak seperti materi pelajaran, ini tidak menjadi kendala dalam pembelajaran fisika.

Salah satu kendala yang dialami adalah jumlah rombongan belajar yang terlalu besar. Jumlah rombongan belajar di MAN Yogyakarta I tiap kelasnya ada 37-40 siswa. Jumlah ini cukup menyulitkan bagi guru untuk mengenali siswa secara individual dalam proses pembelajaran, sehingga prinsip pendidikan karakter untuk memahami 
keberagaman siswa belum bisa terwujud. Selain itu, untuk menilai siswa secara individual juga sulit sehingga biasanya hanya dinilai siswa yang teraktif dan terpasif saja. Untuk mengatasi hal itu guru sering membagi siswa dalam beberapa kelompok, tiap kelompok terdiri dari 3-5 siswa sehingga jumlah rombongan belajar setelah dibagi kelompok menjadi 8-12 kelompok. Hal ini akan mempermudah guru dalam menilai baik aspek kognitif, afektif, dan psikomotorik karena di dalam kelompok biasanya guru memberikan suatu masalah yang harus dipecahkan oleh siswa. Dalam memecahkan masalah tersebut biasanya timbul sikap cerminan pendidikan karakter seperti kerja sama, kreativitas, kehati-hatian, keaktifan, dan keterampilan lainnya. Selain itu, untuk mengatasi jumlah rombongan belajar yang besar pada kelas XI dan XII, dalam mengajar guru membentuk team teaching.

Peran laboratorium belum difungsikan secara maksimal sehingga ada beberapa alat praktikum yang rusak bukan karena sering dipakai, tetapi rusak karena berkarat dan jarang digunakan. Hal ini disebabkan oleh beberapa faktor di antaranya jumlah jam pelajaran fisika yang masih kurang sehingga kegiatan praktikum jarang dilakukan. Namun, faktor utamanya adalah guru fisika MAN Yogyakarta sendiri yang jarang menggunakan metode eksperimen dalam proses pembelajaran.

Masalah yang cukup serius dan tidak hanya terjadi di MAN Yogyakarta I, tetapi umumnya juga terjadi di sekolah lain adalah minat baca siswa umumnya yang masih rendah. Rendahnya minat baca siswa ini disebabkan salah satunya, kurangnya sosialisasi pentingnya membaca dari guru kepada siswa sehingga kesadaran siswa tentang pentingnya membaca masih rendah, padahal budaya membaca salah satu yang bisa mengembangkan karakter siswa. Siswa mempunyai anggapan buku fisika yang tersedia kurang menarik karena penuh dengan rumus-rumus fisika. Anggapan seperti ini harus segera ditangani, salah satu cara yang dipakai oleh salah satu guru fisika di MAN Yogyakarta I dengan memberikan tugas meringkas kepada siswa untuk materi pelajaran yang akan disampaikan pada pertemuan selanjutnya. Hal ini dinilai oleh guru cukup efektif karena siswa dipaksa untuk membaca sehingga lama kelamaan siswa akan terbiasa dan paksaan yang dirasakan oleh siswa akan berubah menjadi kesenangan bahkan hobi. Masalah lain yang cukup menghambat implementasi pendidikan karakter adalah jumlah jam pelajaran fisika di MAN Yogyakarta I, terutama kelas $X$ yang menurut kurikulum MAN Yogyakarta I hanya 2 jam pelajaran setiap minggunya. Pelajaran fisika hanya 2 jam perminggu karena harus berbagi dengan pelajaran agama seperi fikih, akidah akhlak, Quran hadis, sejarah kebudayaan Islam yang merupakan ciri khas madrasah. Hal ini dinilai kurang oleh guru untuk memaksimalkan pendidikan karakter dan potensi siswa dalam belajar fisika. Belajar fisika tidak hanya bisa secara teoretis saja, tetapi diharapkan secara skill dan afektif dapat dikembangkan, misalnya melalui kegiatan eksperimen. Dua jam pelajaran dalam semingguhanyacukup untuk menyampaikan materi secara teoretis saja, sedangkan materi dan kompetensi yang harus dikuasi siswa banyak sehingga kegiatan seperti eksperimen tidak dilaksanakan pada jam regular.

Selain masalah di atas, masalah lain yang timbul adalah guru merasa kekurangan waktu dalam mengembangkan strategi dan metode pembelajaran sehingga proses pembelajaran berlangsung efektif dan efisien. Guru juga terhambat masalah sumber 
(referensi) dalam pengembangan modelmodel pembelajaran fisika. Menurut pengamatan peneliti sebagian guru fisika di MAN Yogyakarta I merasa kesulitan untuk mengubah dirinya yang semula mengajar dengan sistem teacher centered harus berubah menjadi student centered. Hal ini disebabkan ego guru yang kadang keluar dan sulit dikendalikan. Untuk mengatasi hal itu madrasah mengefektifkan Musyawarah Guru Mata Pelajaran (MGMP) madrasah dan senantiasa mendorong guru untuk aktif dalam kegiatan MGMP baik di tingkat kabupaten maupun di tingkat provinsi. Kegiatan MGMP tingkat Kota Yogyakarta dilaksanakan setiap satu minggu sekali, yaitu setiap hari Kamis.

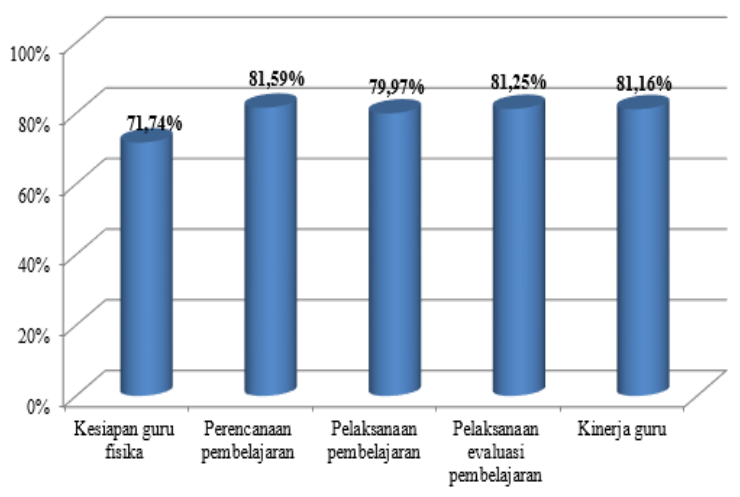

Gambar 5. Hasil Evaluasi CIPP Implementasi Pendidikan Karakter dalam Pembelajaran Fisika

Secara keseluruhan, implementasi pendidikan karakter dalam pembelajaran fisika di MAN Yogyakarta I berdasarkan pada data kuantitatif yang meliputi: hasil konteks (kesiapan guru fisika mengimplementasikan pendidikan karakter), input (perencanaan pembelajaran fisika), proses (pelaksanaan pembelajaran fisika, dan pelaksanaan evaluasi pembelajaran fisika), dan hasil (kinerja guru) memiliki kategori baik dengan persentase rata-rata 79,14\% dengan persentase masing-masing aspek disajikan pada Gambar 5.

\section{PENUTUP}

Berdasarkan evaluasi implementasi pendidikan karakter di MAN Yogyakarta I dapat disimpulkan seperti berikut.

- MAN Yogyakarta I telah cukup baik dalam mengimplementasikan pendidikan karakter pada pembelajaran fisika ditandai dengan timbulnya sikap religius, jujur, toleransi, disiplin, kerja keras, kreatif, mandiri, demokratis, rasa ingin tahu, semangat kebangsaan, cinta tanah air, menghargai prestasi, bersahabat/komunikatif, cinta damai, gemar membaca, peduli lingkungan, peduli sosial, dan tanggung jawab. Guru menumbuhkan sikap-sikap tersebut dalam proses pembelajaran.

- Evaluasi implementasi pendidikan karakter dalam pembelajaran fisika dengan model CIPP di MAN Yogyakarta I menunjukkan bahwa: (1) Kesiapan guru fisika berada pada kategori baik dengan persentase rata-rata $71,74 \%$; (2) perencanaan pembelajaran oleh guru fisika memiliki kategori baik dengan persentase rata-rata $81,59 \%$, dengan aspek-aspek perencanaan pembelajaran meliputi: identifikasi kebutuhan KBM sangat baik $(91,67 \%)$, penyusunan silabus sangat baik $(84,38 \%)$, penyusunan RPP sangat baik $(81,06 \%)$; (3) pelaksanaan pembelajaran oleh guru fisika yang meliputi kegiatan prapembelajaran, membuka pelajaran, dan kegiatan inti pembelajaran adalah baik dengan persentase 79,97\%; (4) pelaksanaan evaluasi pembelajaran fisika meliputi evaluasi formatif, evaluasi sumatif, evaluasi kelas, dan tugas berada pada kategori baik dengan persentase $81,25 \%$; dan (5) kinerja guru fisika dalam mengimplementasikan pendidikan karakter yang meliputi: kemampuan mengajar, penggunaan metode dan media pembelajaran, komunikasi, sikap 
dan kepribadian berada pada kategori baik dengan persentase $81,16 \%$.

- Kendala utama yang dihadapi dalam implementasi pendidikan karakter pada pembelajaran fisika di MAN Yogyakarta I berasal dari faktor guru. Alokasi jam pelajaran fisika yang ada pada kurikulum dinilai oleh guru kurang untuk menyampaikan materi pelajaran dan kegiatan eksperimen. Kendala lainnya yang dihadapi adalah jumlah rombongan belajar terlalu besar, laboratorium yang belum difungsikan secara maksimal, dan minat baca siswa yang masih rendah di perpustakaan.

\section{UCAPAN TERIMA KASIH}

Penulis mengucapkan terima kasih kepada Kepala MAN Yogyakarta I yang telah memberikan izin melakukan penelitian ini dan reviewer yang telah memberikan masukan untuk penyempurnaan tulisan ini.

\section{DAFTAR PUSTAKA}

Asmani, Jamal Ma'mur. 2011. Buku Panduan Internalisasi Pendidikan Karakter di Sekolah. Yogyakarta: DIVA Press.
Fathurrahman, P. dkk. 2013. Pengembangan Pendidikan Karakter. Bandung: Refika Aditama.

Gunawan, Heri. 2012. Pendidikan Karakter Konsep dan Implementasi. Bandung: Alfabeta.

Hamid dan Hasan. 2007. "Pengembangan dan Implementasi KTSP, Konsep dan Substansi". Makalah Disajikan dalam Seminar Nasional KTSP, UNNES, Semarang, 15 Maret 2007. Hlm :2-3.

Hamid, Ahmad Abu. 2008. Diktat Pengembangan Profesi Guru Fisika. Yogyakarta: Jurdik FMIPA UNY.

Kun Prasetyo, Zuhdan. 2001. Kapita Selekta Pembelajaran Fisika. Jakarta: Pusat Penerbitan Universitas Terbuka.

Suparno, Paul. 2006. Metodologi Pembelajaran Fisika. Yogyakarta: Universitas Sanata Dharma Yogyakarta. 